Case Report

\title{
Diffuse thoracic and peritoneal papillary mesothelioma in an adult cow: case report
}

\author{
Frank A. O. Toledo ${ }^{*}$, Aline D. B. B. Gonçalves ${ }^{3}$, Mariela F. Toscano ${ }^{2}$, Eduardo H. Fazzano ${ }^{2}$, Fernando \\ V. Fernandes ${ }^{2}$, Geovanni D. Cassali ${ }^{3}$, Daniela B. Rozza ${ }^{2}$ \\ ${ }^{1}$ Escola de Veterinária, Universidade Federal de Minas Gerais, Belo Horizonte, MG. \\ ${ }^{2}$ Serviço de Patologia Veterinária, Universidade Estadual Paulista "Julio de Mesquita Filho", Araçatuba, SP. \\ ${ }^{3}$ Laboratório de Patologia Comparada, Instituto de Ciências Biológicas, Universidade Federal de Minas Gerais, Belo Horizonte, MG. \\ *Corresponding author: toledofrank@ outlook.com
}

Submitted November, $27^{\text {th }} 2017$, Accepted March, $9^{\text {th }} 2018$

\begin{abstract}
Mesothelioma is a rare tumor of mesothelium and usually spread by implantation in the same cavity it arises. Regarding bovine mesotheliomas, the abdominal cavity is the most affected site. This article describes a case of diffuse papillary mesothelioma within both thoracic and abdominal cavity with nodal metastasis in an adult cow - based on cytology, histopathology, and immunohistochemical analysis. A 7-years-old cow, Nelore breed (Brazilian beef cattle), with clinical signs of tachypnea, abdominal distention, and positive jugular venous pulse was slaughtered and necropsied due to persistent weight loss. The main gross findings were several verrucous and yellowish nodules spread on pericardium, pleura, and peritoneum. Mediastinal lymph nodes were enlarged and hemorrhagic with multiples yellowish spots on cut surface. The diagnoses of diffuse mesothelioma with nodal metastasis was established and ratified by the microscopic analysis. Immunohistochemical results had strong positivity for cytokeratin and the Ki-67 showed proliferative index of $28 \%$. Vimentin was positive only in the cells of fibrous tissue. In this case, the initial site of the mesothelioma was not recognized. Although it is a post-mortem study, cytology may be very helpful in vivo investigation. Equally important, is the IHC to better comprehend this tumor and its behavior.
\end{abstract}

Key words: mesothelial cancer, thorax, abdomen, bovine.

\section{Introduction}

Mesothelioma is a rare neoplasm of pleura, pericardium, peritoneum, and tunica albuginea. While pleural mesothelioma is more common in cat, bovine mesothelioma mostly occurs in the peritoneum and may be transferred by contaminated needle or surgical instruments (13). This tumor usually disseminates by detachment and implantation on the same body cavity where it first arises (7) and rarely metastasize to local lymph nodes or distant tissues (8). Macroscopically, mesothelioma (epithelioid form) is seen as multiple nodules multifocal to coalescent scattered throughout the body cavity surfaces (13). The mesothelial neoplastic cells may turn into either epithelial- like or mesothelial-like cells and be histologically classified as epithelioid, sarcomatous, or mixed (17). The papillary pattern (epithelioid subtype) presents exophytic structures lined by a single layer of mesothelial cells with a central support of connective tissue (17). Both mesothelium and fibrous tissue may behave with malignancy and microscopically to resemble either carcinoma or fibroblastic sarcoma $(13,17,27)$.

Diagnosing mesothelioma by cytological samples may be challenging $(11,17,27)$ and have to be carefully examined. Despite this, cytological evaluation of fluid is very useful to distinguish inflammatory from neoplastic processes (16). The cavity fluid, one of the main and earliest clinical signs, when analyzed affords a suggestive 
diagnose that combined with others complementary exams increased the potential of in vivo diagnosis and prognosis (14). In mesotheliomas, there are numerous clusters of polygonal cells presenting one or multiple nuclei, granular chromatin, irregular and prominent nucleolus, inconstant nuclear cytoplasmic ratio, and high cell pleomorphism (21).

Immunohistochemistry has an important role in association with the morphology analysis to the establishment of diagnosis and therapy of tumors (20). Nevertheless, in veterinary medicine the antibodies are still unspecific for the identification of mesotheliomas (27). Hereafter, we describe the cytological, histological, and immunohistochemical findings of papillary mesothelioma into the thoracic and abdominal cavity including nodal metastasis in a cow (Bos indicus).
A 7-years-old cow, Nelore breed (Brazilian beef cattle), was slaughtered due to persistent weight loss. The clinical signs were tachypnea, positive jugular venous pulse, and severe abdominal distention. The main differential diagnosis was enzootic bovine leukosis. At necropsy, high quantity of blood-tinged fluid flowed from the abdominal cavity. The peritoneum was covered by verrucous yellowish nodules, $0.5 \mathrm{~cm}$ to $3.0 \mathrm{~cm}$ in diameter, multifocal to coalescent, firm, and occasionally they became small plaques. The nodules were spread on surface of several organs and did not invade the parenchyma. Same lesions were also seen covering the pericardium and scattered on the pleura. The lesions within the thorax were more severe and the nodules were greater than those from the abdomen, and they were coalescing to the pericardium. Into the abdomen, the tumor development was more intense on surfaces of diaphragm, rumen, and spleen. The nodal metastasis was observed only in the mediastinal lymph nodes that were enlarged and congested with multiples yellowish spots on cut surface (Fig. 1).

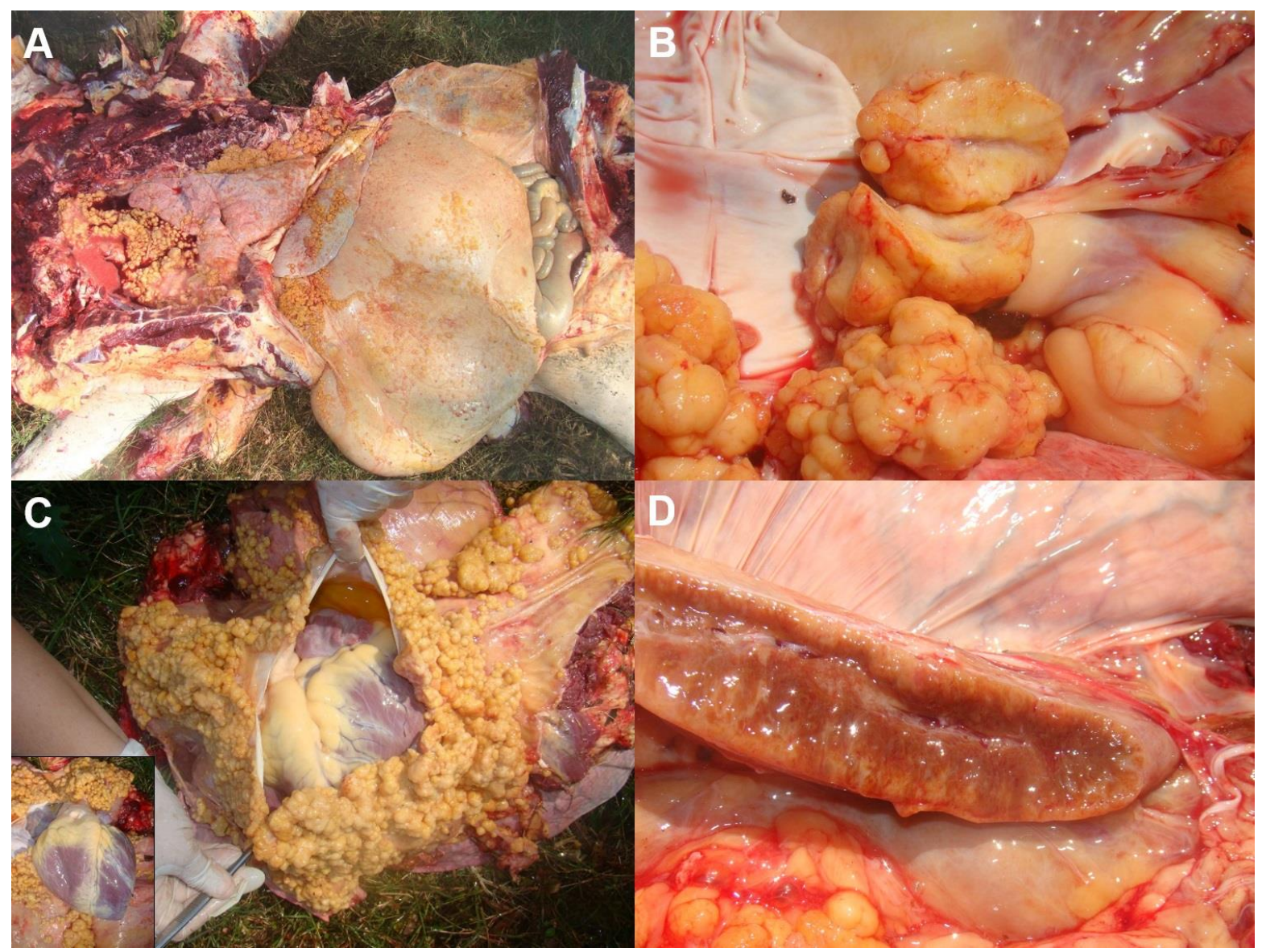

Figure 1. Gross findings of papillary mesothelioma spread on peritoneum, pleura, and pericardium. A. Uncountable nodules scattered in both thoracic and abdominal cavity. The verrucous and yellowish tumors were multifocal to coalescent, firms, $0.5 \mathrm{~cm}$ to $3.0 \mathrm{~cm}$ in diameter, and occasionally became small plaques. B. Cut surface of the nodules showing a whitish and depressed line of fibrous tissue. C. Pericardium diffusely covered by the nodules which did not invade either pericardial space nor the heart. D. Cut surface of mediastinal lymph node with congestion and yellowish spots. 
Cytology analysis of effusions revealed high cellularity even before centrifugation. Using a sterile syringe, one drop of effusion was smashed between two glass microscope slides. Next, the samples were stained by fast panoptic kit (fifteen seconds each preps). Microscopically, dense clusters of cells (approx. 30 to 40 cells) with other smaller groups, characterized by acini-like arrangements, and few solitary and high pleomorphic spindle cells were observed. The cells were round to polygonal with high pleomorphism, one or multiple nucleus, loose chromatin, and prominent nucleolus (Fig. 2). Aberrant mitosis was rarely seen, and that is why it is not represented hereinafter.

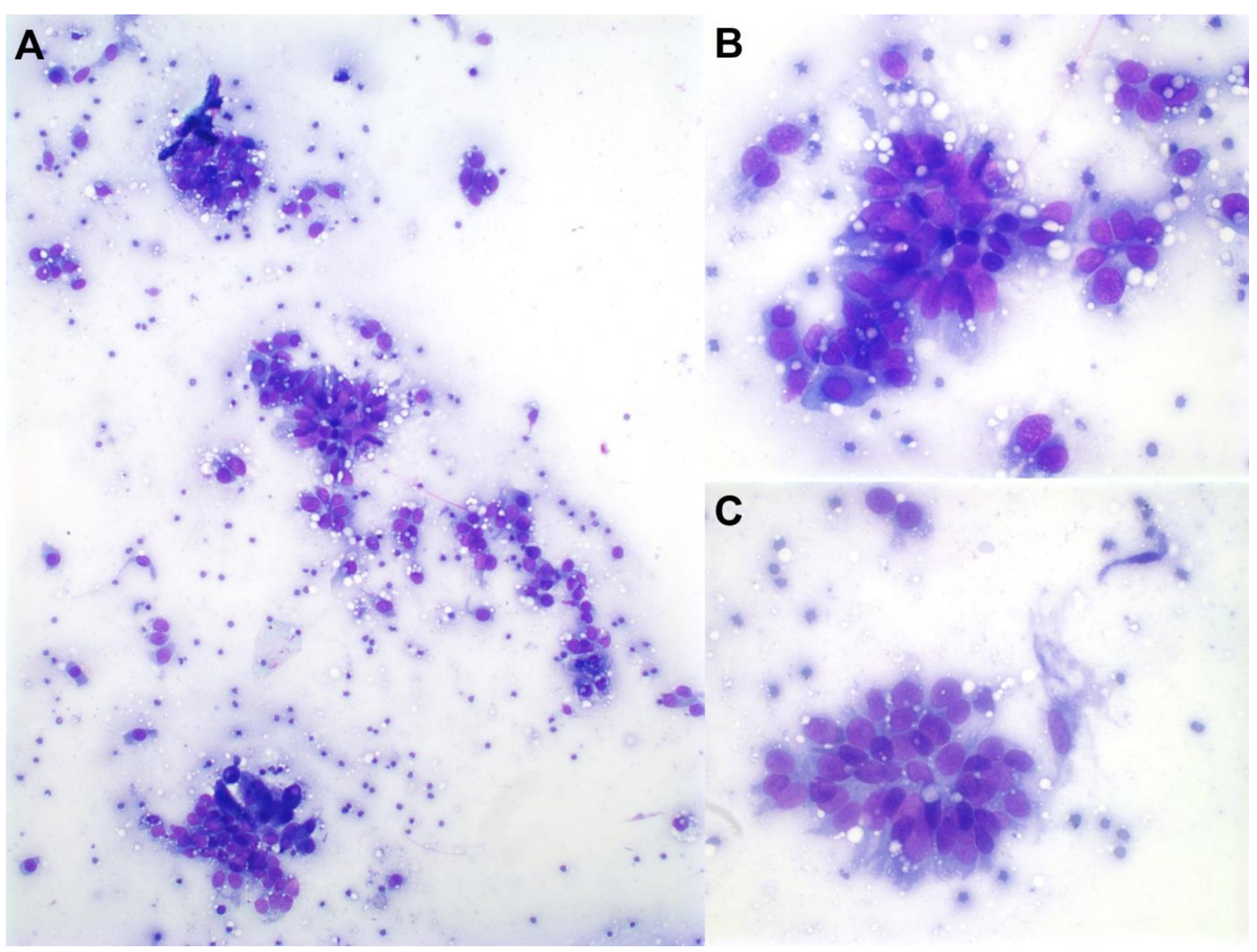

Figure 2. Cytology features of the papillary mesothelioma in non-centrifuged effusion. A. High cellularity fields represented by dense clusters of cells (200x). B. Dense cluster of round to polygonal cells surrounded by some smaller groups with acinus-like arrangement. The cells are characterized by high pleomorphism, one or multiple nucleus, loose chromatin, and prominent nucleolus (600x). C. Dense cluster of neoplastic cells followed by a pleomorphic spindle cell (600x).

Histologically, the papillary outgrowths were characterized by a single cell layer with central thin connective tissue (Fig. 3A and 3B). The mediastinal lymph nodes showed metastatic emboli in both subcapsular and medullary lymphatic sinuses (Fig. 3C and 3D). 


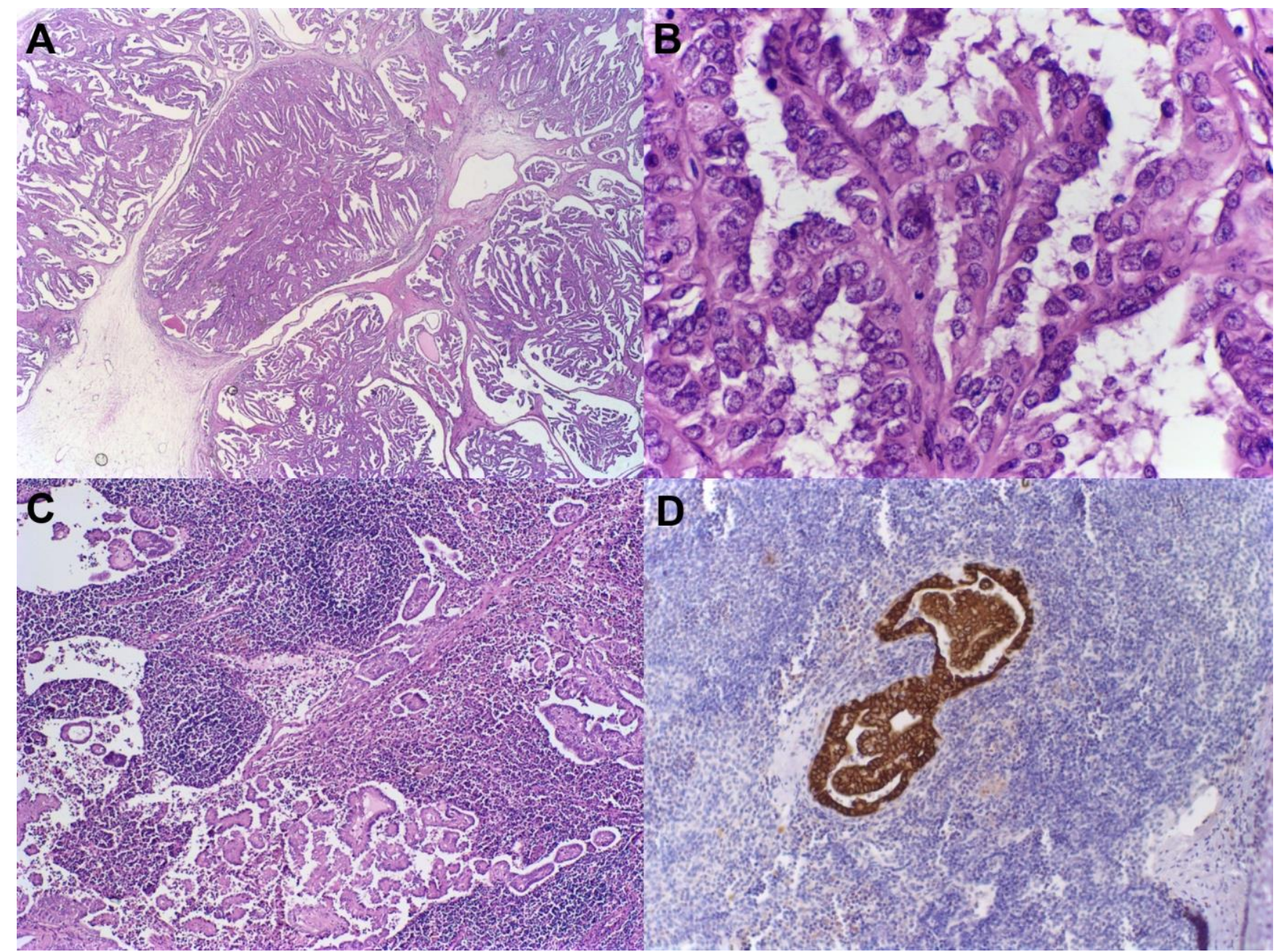

Figure 3. Histopathology of papillary mesothelioma with nodal metastasis. A. Papillary pattern of the mesothelioma (HE, 20x). B. Single layer of cells with a thin central connective tissue (HE, 600x). C. Mediastinal lymph nodes. Neoplastic emboli surrounding the follicles by the invasion of both subcapsular and medullary sinuses (HE, 100x). D. Mediastinal lymph nodes. Neoplastic emboli represented by strong reaction with Cytokeratin (200x).

Immunohistochemical tests were performed with the sections of formalin-fixed paraffin-embedded specimens that were stained by cytokeratin, vimentin, and Ki-67. Endogenous peroxidase activity was neutralized using the Novolink ${ }^{\mathrm{TM}}$ peroxidase block which was applied three times over 45 minutes (three changes, 15 minutes each). Polymer and chromogen (DAB) were also from the Novolink $^{\mathrm{TM}}$ and was applied according to its datasheet. Description of the antibodies and their techniques are detailed in Table 1.

The assessment of the cytokeratin and vimentin reactions was made by qualitative identification.
Mesothelial cells showed strong cytoplasmic positivity for cytokeratin in both lymph node and tumor samples. The spindle cells of the connective tissue had strong cytoplasmic positivity for vimentin. The Ki-67 response was estimated by calculating both negative and positive cells pointed with the Java-based image processing program (ImageJ software) per 10 high power (400x) fields. The Ki67 showed moderate to strong nuclear positivity and reached the average of $28 \%$ labeling index (Fig. 4). 
Table 1. Description of the antibodies and immunohistochemical procedures.

\begin{tabular}{lllll}
\hline $\begin{array}{l}\text { Target Antigen } \\
\text { (Clone) }\end{array}$ & Company & Dilution & Antigen Retrieval Method & $\begin{array}{l}\text { Incubation Time (h) } \\
\text { /Temperature ( }\end{array}$ \\
\hline $\begin{array}{l}\text { KI-67 } \\
\text { (MIB-1) }\end{array}$ & DAKO & $1: 50$ & $\begin{array}{l}\text { Pressurized Heat }\left(125^{\circ} \mathrm{C} / 2 \mathrm{~min}\right) \\
\text { with citrate buffer } \mathrm{pH} 6.0\end{array}$ & Overnight $(18 \mathrm{~h}) / 4^{\circ} \mathrm{C}$ \\
$\begin{array}{l}\text { Cytokeratin } \\
\text { (AE1/AE3) }\end{array}$ & DAKO & $1: 500$ & $\begin{array}{l}\text { Pressurized Heat }\left(125^{\circ} \mathrm{C} / 2 \mathrm{~min}\right) \\
\text { with citrate buffer } \mathrm{pH} 6.0\end{array}$ & Overnight $(18 \mathrm{~h}) / 4^{\circ} \mathrm{C}$ \\
$\begin{array}{l}\text { Vimentin } \\
\text { (Vim 3B4) }\end{array}$ & DAKO & $1: 500$ & $\begin{array}{l}\text { Pressurized Heat }\left(125^{\circ} \mathrm{C} / 2 \mathrm{~min}\right) \\
\text { with citrate buffer } \mathrm{pH} 6.0\end{array}$ & Overnight $(18 \mathrm{~h}) / 4^{\circ} \mathrm{C}$ \\
\hline
\end{tabular}
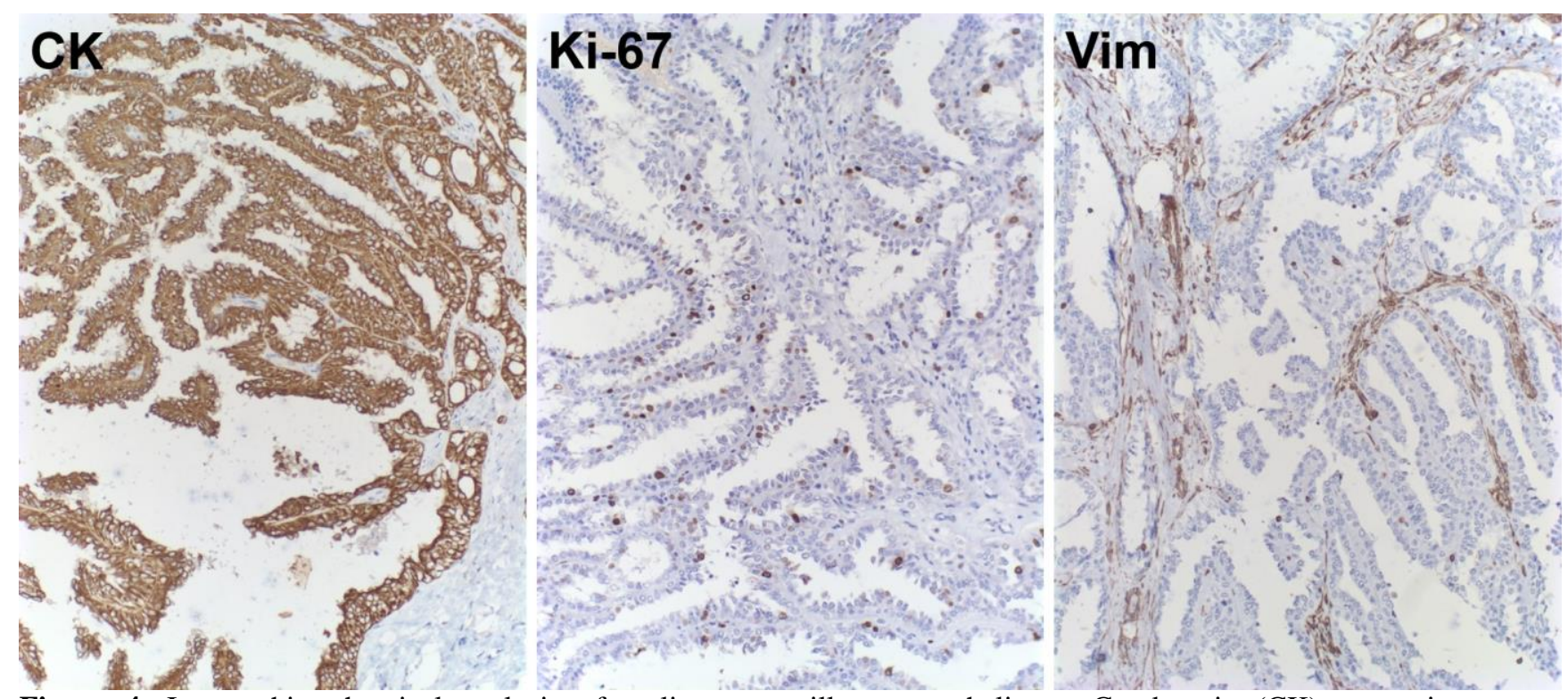

Figure 4. Immunohistochemical analysis of malignant papillary mesothelioma. Cytokeratin (CK) presenting strong cytoplasmic reaction in mesothelial cells; Ki-67 with moderate to strong nuclear positivity and $28 \%$ of labeling index; Vimentin (Vim) showing strong cytoplasmic positive in the fusiform cells belonging the thin layer of connective tissue (Novolink ${ }^{\mathrm{TM}}$ Polymer Detection System, Harris's hematoxylin counterstain, 200x).

\section{Discussion}

Regarding the clinical differential diagnosis, neoplastic diseases was considered, once infectious etiology wasn't not clear. In this case, the animal had no fever and the main sign reported by the veterinarian was associated with severe abdominal distention. This condition may have many causes and seems to be uncommon in cattle, and ascites caused by mesotheliomas are even more infrequent. During a 5-year study in Scotland, only 9 of 1836 cattle had signs of ascites. Among them, one was related to diffuse peritoneal mesothelioma (16). Two universities from United States (Alabama and Louisiana) in an 8 -year period, reported that 3 of 8 beef cattle with mesothelioma had abdominal distension (29). In Brazil, no cases of mesothelioma were found in a 45-years retrospective study accomplished by the Federal University of Santa Maria. This data refers to 586 archived cases of tumors in cattle subsequent to more than six thousand necropsies. Only three cases were related to tumors spread on the peritoneum and pleura. Two of them were diagnosed as dissemination of adenocarcinoma and one as hemangiosarcoma of the lung and mediastinum (14).

Pleural mesothelioma is common in cat while peritoneal mesothelioma is more frequently seen in bovine $(13,17)$. Mesothelioma disseminated in both peritoneal and pleural cavity seems to be even rarer. This case reports a Bos indicus cow presenting mesothelioma within both abdomen and thorax with mediastinal lymph node metastasis, with nodules spread on the pericardium, pleura, and peritoneum. Similar to this, a single report of a Swiss Braunvieh cow (Bos taurus) also had mesothelioma in abdominal and thoracic cavities. In that case, the tumors present solid and papillary pattern with large amount of connective tissue, and the metastases were seen in ileocecal lymph nodes (4). In a dog with mesothelioma in 
pleura and peritoneum, the pericardium was not affected, and the lymph nodes were not investigated (15).

Although mesothelioma may be transferred by contaminated instruments (13), there was no evidence of using the same needle in both cavities in this case. Intravenous fluid therapy was made only by jugular route. Besides, there was no evidence of other affected animals in the herd. Metastasis of mesothelioma to lymph node and other organs may occur but is rarely described in the literature. A particular case of peritoneal sclerosing mesothelioma with hepatic and pulmonary metastasis in a crossbreed cow was reported, but the lymph nodes were not described (3). This pattern of mesothelioma differs on the considerable amount of fibrous tissue and tubular structures filled by necrotic debris.

Macroscopically, granulomatous peritonitis and pleuritis may appear similar to mesotheliomas (3). However, effusions tend to opacity due to the presence of leukocytes and inflammatory sings may be seen around the lesions. The partial or fully absence of adhesions may also be helpful to this differentiation (27). A diagnosis of mixed mesothelioma displaying cystic variation in a Swiss cow was triggered by the presence of 248.5 liters of noninflammatory ascites (5). Carcinomas of the ovary, prostate, pancreas, bile duct, gastrointestinal tract, and urinary bladder may metastasize to peritoneum $(17,27)$. In this present case, these organs had no alterations and had no parenchyma invasion in histologic sections. This same condition was confirmed in the thoracic organs.

The main challenge in cytology analysis of mesothelioma is to distinguish it from reactive mesothelial cells, considering that in both cases the cells present morphological atypia and increase of cellularity $(11,17)$. However, a higher cellularity and presence of greater clusters of cells are seen in neoplastic process of mesothelium (15). In this report, a small number of solitary spindle cells with high pleomorphism were also seen, which correspond to the proliferation of connective tissue.

Immunohistochemical analysis of effusions, may be valuable to differentiate the reactive mesothelial cells from malignant counterparts. In one study, the labeling index of Ki67 had an average of $24.6 \%$ and $6.23 \%$ for malignant and benign mesothelial cells respectively. Using the cut-off of $\geq 9 \%$, the sensitivity was $88 \%$ and specificity $92 \%$ (25). In human effusions, IHC analysis in cell block technique had no substantial differences between Ki67 results of malignant and reactive mesothelial cells. Unlikely, the results of combined immunoprofile of epithelial membrane antigen (EMA), glucose-transport protein (GLUT-1), desmin, and p53, showed better data and favored the diagnoses of this tumor (11). The authors also highlighted that mesothelial reactive cells may have high mitotic index and effusion contaminated with proliferating lymphocytes may confuse the Ki67 labeling. In this report, instead of effusion investigation of proliferative index, Ki67 was performed in histologic sections and showed $28 \%$ of proliferative index. For the sake of comparison, more studies are still necessary for the establishment of prognosis.

In histological sections, both mesothelial and mesenchymal cells may behave malignant and morphologically to resemble either carcinoma or fibrosarcoma $(13,17)$. Such as represented by this case, the papillary outgrows must be differentiated from metastases of adenocarcinomas. In bovines, intestinal adenocarcinoma has a tendency to be scirrhous (27). In a report of Holstein cow simultaneously affected by both mesothelioma and ovarian tumor, authors emphasized the presence of multilayered epithelial cells and absence of neoplastic connective tissue in the ovarian neoplasm, while mesothelioma showed a single layer of epithelial cells underlying fibroblasts (10). Other types of peritoneal neoplasms in cattle is unusual, but there is a report of embryonal carcinoma in a male calf. In that case, the polygonal cells were arranged in solid pattern and rarely presented papillary or tubular structures (1). In women, the majority of the peritoneal papillary carcinomas were categorized by small and crowded cells with hyperchromatic nuclei, while mesotheliomas presented larger cells with more abundant cytoplasm and vesicular nuclei (12).

In addition to the challenge of establishing the malignant status of the tumor, mesotheliomas have to be differentiated from other carcinomas. Some reports in animals describe positive reaction for cytokeratin and vimentin in mesothelial cells $(9,26,28)$. Intrapericardial development of mesothelioma was described in neonatal calf with the neoplastic cells presenting positivity for both cytokeratin and vimentin (26). Pericardial mesothelioma in a Bengal tiger also presented positivity for both cytokeratin and vimentin. And the authors emphasized that the analysis was done with successive tissue sections from the same paraffin block (28). In a German Shepherd dog, pericardial mesothelioma had weak cytokeratin positivity and intense vimentin reaction (6).

In our IHC analysis, the layer of mesothelial cells showed positivity only for cytokeratin, while the spindle cells from the connective tissue were positive only for vimentin. The case of Swiss cow with thoracic and abdominal mesothelioma had same results (4). In contrast, a sarcomatous mesothelioma in a 2-years-old cow showed cytokeratin negative reaction and strong positivity for vimentin (19). Although many authors have cited cytokeratin and vimentin mesothelial co-expression, vimentin positive labelling may be expressed by different percentages of mesotheliomas and other carcinomas. In a study of immunohistochemical diagnostic panel for human mesotheliomas, 11 of 57 (19\%) epithelioid mesotheliomas were vimentin negatives (22). Besides, above $50 \%$ of the papillary adenocarcinomas of thyroid, ovary, endometrium, kidney, and lung carcinomas also had coexpression of both cytokeratin and vimentin (2). Consequently, the observation of this antibodies co- 
expression alone is not crucial to the diagnosis once it does not confirm mesothelioma nor excludes its differentials.

Considering that the cytokeratin and vimentin antibodies are limited and their coexpression is more common than reported (2), other markers may also be important to the study of mesotheliomas. Sclerosing mesothelioma spread on peritoneum and spermatic cord in a dog showed strong positivity for cytokeratin and protein S100 (23). In this same case report, human mesothelial anti-cell (HBME-1) presented a multifocal reaction instead the diffuse pattern seen in human samples. Consequently, the authors were not confident to confirm the use of HBME-1 as a substantial marker in animal mesothelial tumors. Mesothelin has also been used mainly in dogs and cats, but its specificity still unknown in animals (20). Calretinin, a cytoplasmic calcium-binding protein, was used as immunostaining and showed strong positivity in an equine with metastatic mesothelioma (24). Claudin-4 (CL4) is an absent protein in mesothelial cells, but it is expressed in almost all epithelial cells. Then, CL-4 immunostaining may be helpful to differentiate mesotheliomas from carcinomas. In a human research, all mesotheliomas were negative and $91 \%$ of carcinomas were positive for this marker (18). As neither histochemistry nor immunohistochemistry had not been succeeded in the exclusive identification of malignant mesothelial cells in animals (27), more studies are still necessary for better understanding and usage of this markers.

In conclusion, the first site of the mesothelioma development in this present case was not established. Even though there was greater severity on pericardium associated with mediastinal lymph node metastasis, the authors did not point this area as earliest site of growth. Without molecular tests or other sophisticated analysis, any attempt to define the primary site of the tumor development would be considered an empirical act. Grossly and histologically, the diagnosis was not challenging in this particular epithelioid case, and it was definitely done by eosin and hematoxylin stain. Nevertheless, the findings do not exclude the relevance of immunohistochemistry, to better characterizes the mesothelioma, especially when many antigens and their interactions are still unknown in veterinary medicine. Besides, immunohistochemical tests may be very useful in vivo evaluation in both effusion cell blocks and tissue specimens. Cytology smears of the fluids may also be helpful as a fast and cheap complementary tool to establish the clinical intervention and prognosis.

\section{References}

1. Aihara N, Yamamoto N, Takagi T, Une Y. Embryonal carcinoma in the abdominal cavity of a male calf. $\mathbf{J}$ Vet Diagn Invest. 2011;23(3):598-602.

2. Azumi N, Battifora H. The distribution of vimentin and keratin in epithelial and nonepithelial neoplasms. A comprehensive immunohistochemical study on formalin- and alcohol-fixed tumors. Am J Clin Pathol. 1987;88(3):286-96.

3. Beytut E. Metastatic sclerosing mesothelioma in a cow. Aust Vet J. 2002;80(7):409-11.

4. Braun U, Gerspach C, Metzger L, Ziegler-Gohm D. Ultrasonographic findings in a cow with ascites due to a mesothelioma. Vet Rec. 2004;154(9):272-4.

5. Braun U, Rütten M, Bleul U, Previtali M, Krüger S, Gerspach C, Geiger S, Sydler T. Biphasic mesothelioma in a Swiss Braunvieh cow: clinical, histological, immunohistochemical and electron microscopical findings. Schweiz Arch Tierheilkd. 2012;154(1):33-8.

6. Ceribasi S, Ozkaraca M, Ceribasi AO, Ozer H. Pericardial mesothelioma in a German Shepherd dog: a case report. Veterinarni Medicina. 2013;58(11):5948.

7. Cullen JM, Breen M. An Overview of Molecular Cancer Pathogenesis, Prognosis, and Diagnosis. In: Meuten DJ, editor. Tumors of Domestic Animals. 5th ed. Ames, Iowa: John Wiley \& Sons Inc.; 2017. p. 126.

8. Gelberg HB. Sistema alimentar, peritônio, omento, mesentério e cavidade peritoneal. In: McGavin DM, Zachary JF, editors. Bases da Patologia Veterinária. 2nd ed. Rio de Janeiro: Elsevier; 2013. p. 403-6.

9. Girard CA, Cécyre A. Diffuse abdominal epithelioid mesothelioma in a cow. Can Vet J. 1995;36(7):440-1.

10. Hashimoto N, Oda T, Kadota K. An ultrastructural study of malignant mesotheliomas in two cows. Nihon Juigaku Zasshi. 1989;51(2):327-36.

11. Hasteh F, Lin GY, Weidner N, Michael CW. The use of immunohistochemistry to distinguish reactive mesothelial cells from malignant mesothelioma in cytologic effusions. Cancer Cytopathol. 2010;118:906.

12. Kannerstein M, Churg J, McCaughey WTE, Hill DP. Papillary tumors of the peritoneum in women: Mesothelioma or papillary carcinoma. Am J Obstet Gynecol. 1977;127(3):306-14.

13. Lopez A. Sistema respiratório, mediastino e pleuras. In: McGavin DM, Zachary JF, editors. Bases da Patologia Veterinaria. 2nd ed. Rio de Janeiro: Elsevier; 2013. p. 403-6.

14. Lucena RB, Rissi DR., Kommers GD, Pierezan F, Oliveira-Filho JC, Macedo JTSA, Flores MM, Barros CSL. A Retrospective Study of 586 Tumors in Brazilian Cattle. J Comp Path. 2011;145(1):20-4.

15. Martins DB, Souza GS, Pedrozo JCSR, Mazzanti CM, Mazzanti A, Beckmann DV, Santos RP, Graça DL, Lopes STA. Thoracic and abdominal mesothelioma in a dog: a cytologist's view. Comp Clin Pathol. 2011;20(3):289-93.

16. Milne MH, Mellor DJ, Barrett DC, Fitzpatrick JL. Observations on ascites in nine cattle. Vet Rec. 2001;148(11):341-4. 
17. Munday JS, Löhr CV, Kiupel M. Tumors of the Alimentary Tract. In: Meuten DJ, editor. Tumors of Domestic Animals. 5th ed. Ames, Iowa: John Wiley \& Sons Inc.; 2017. p. 499-601.

18. Ordóñez NG. Value of Claudin-4 Immunostaining in the Diagnosis of Mesothelioma. Am J Clin Pathol. 2013;139(5):611-19.

19. Pizarro M, Brandau C, Sanchez MA, Flores JM. Immunocytochemical identification of a bovine peritoneal mesothelioma. Zentralbl Veterinarmed A. 1992;39(6):476-80.

20. Ramos-Vara JA, Borst LB. Immunohistochemistry: Fundamentals and Applications in Oncology. In: Meuten DJ, editor. Tumors of Domestic Animals. 5th ed. Ames, Iowa: John Wiley \& Sons Inc.; 2017. p. 4487.

21. Alan H. Rebar and Craig A. Thompson. Fluidos de cavidade corporal. In: Raskin RE, Meyer DJ., editors. Citologia clínica de cães e gatos: atlas colorido e guia de interpretação. 2nd ed. Rio de Janeiro: Elsevier; 2011. p. 186-89

22. Riera JR, Astengo-Osuna C, Longmate, JA, Battifora $\mathrm{H}$. The immunohistochemical diagnostic panel for epithelial mesothelioma: a reevaluation after heatinduced epitope retrieval. Am J Surg Pathol. 1997;21(12):1409-19.

23. Sekarides R, Cassali GD, Santana FJF, Nascimento EF. Peritoneal mesothelioma in dog: a case report. Arq Bras Med Vet Zootec. 2001;53(2):1-5.

24. Stoica G, Cohen N, Mendes O, Kim HT. Use of immunohistochemical marker calretinin in the diagnosis of a diffuse malignant metastatic mesothelioma in an equine. J Vet Diagn Invest. 2004;16: 240-3.

25. Taheri ZM, Mehrafza M, Mohammadi F, Khoddami M, Bahadori M, Masjedi MR. The Diagnostic Value of Ki-67 and repp86 in distinguishing between benign and malignant mesothelial proliferations. Arch Pathol Lab Med. 2008;132(4):694-7.

26. Takasu M, Shirota K, Uchida N, Iguchi T, Nishii N, Ohba Y, Maeda S, Miyazawa K, Murase T, Kitagawa H. Pericardial mesothelioma in a neonatal calf. J Vet Med Sci. 2006;68(5):519-21.

27. Uzal FA, Plattner BL, Hostetter JM. Alimentary System. In: Maxie MG, editor. Jubb, Kennedy and Palmer's Pathology of Domestic Animals. 6th ed. Vol. 2. St Louis: Elsevier; 2016. p. 256-7.

28. Wiedner EB, Isaza R, Lindsay WA, Case AL, Decker $\mathrm{J}$, Roberts J. Pericardial mesothelioma in a Bengal tiger (Panthera tigris). J Zoo Wildl Med. 2008;39(1):121-3.

29. Wolfe DF, Carson RL, Hudson RS, Boosinger TR, Mysinger PW, Powe TA Jr, Claxton MS, Angel KL. Mesothelioma in cattle: eight cases (1970-1988). J Am Vet Med Assoc. 1991;199(4):486-91. 